\title{
Enhancing the Intercultural Competence Development of Prospective Music Teacher Education: A Case Study in Indonesia
}

\author{
Sandie Gunara ${ }^{1} \&$ Toni Setiawan Sutanto ${ }^{1}$ \\ ${ }^{1}$ Music Education Department, Universitas Pendidikan Indonesia, Bandung, Indonesia \\ Correspondence: Sandie Gunara, Music Education Department, Universitas Pendidikan Indonesia, Bandung, \\ Indonesia.
}

Received: October 7, 2020

Accepted: January 7, 2021

Online Published: January 9, 2021

doi:10.5430/ijhe.v10n3p150

URL: https://doi.org/10.5430/ijhe.v10n3p150

\begin{abstract}
Music teacher education institutions in Indonesia are challenged to address their students' intercultural needs due to increasing interaction at the global level. Therefore, this research seeks to discover suitable formulation for teacher education institutions in Indonesia in implementing music teacher education and training to equip them with intercultural competence. This research employs case study design, in which the data were obtained using interview conducted in July and August 2020. This aims at obtaining concepts based on the need analysis of intercultural competence through processes, actions and interactions from the participants' perspective. The participants were students of Music Teacher Education Department of Universitas Pendidikan Indonesia, Bandung, West Java, Indonesia. The findings show that 1) the sensitivity to cultural diversity of music teacher candidates needs to be enhanced to expand the awareness of their own and other cultures; and 2) enhancing intercultural competence requires both theoretical and practical courses related to Indonesian identity and global culture. The findings are significant considering that every music teacher should have the same perception in teaching, which is in accordance with the diversity of Indonesian and world cultures.
\end{abstract}

Keywords: cultural diversity, intercultural competence, music teacher education

\section{Introduction}

\subsection{Background}

Possessing intercultural experiences for student music teacher candidates is urgent needed considering that global level interactions have increased and become a regular routine (Banks \& McGee Banks, 2019; H. Westerlund et al., 2015). For example, in Germany, the country has been exposed to cultural diversity with the emergence of immigrants, refugees, and the increasing movement of people in the context of European society (Sukmayadi \& Gunara, 2018). Similarly, Indonesian is experiencing cultural diversity in the context of diversity of race, ethnicity, language, religion, culture and art. This indicates that teacher education offering intercultural values must be improved.

Emmanuel (2003) proposed the notion that teachers must face and test themselves against diversity; hence, they are able to get along with diverse learners as well. The ability of teachers to be intercultural is reflected on how they respond and see their students' diversity, both strengths and weaknesses, and vice versa (Craig et al., 2000; Emmanuel, 2003). In addition, Emmanuel's (2003) study revealed that most teacher candidates have good confidence about their personal backgrounds and life experiences; however, it actually affects the way they teach in class. If the teacher's cultural beliefs are unconsciously carried over to the classroom, the information presented in the classroom might be conveyed under the schemes of their own culture. Unfortunately, this possibly leads to cultural miscommunication or misunderstanding.

A similar case was observed in music teacher candidates during Program Pengalaman Lapangan (PPL/Field Experience Program) or a teaching internship at school. It has been identified that there is still a gap between teachers and students. Most of these music teacher candidates still teach with their own cultural schemes, without understanding the socio-cultural context of their students. Many of the teaching materials delivered are far from the students' initial understanding, resulted in incomplete teaching materials. It is not merely linked to the delivery of music, but also a misunderstanding of school conditions. They consider that complete music learning support facilities must be available to support the curriculum implementation. However, the school condition in rural areas 
needs to be considered since it would be different when being compared. This indicates gaps where: (1) music teacher candidates have not grown their sensitivity to cultural diversity yet due to their lack of experiences in seeing things from the perspective of other cultures; (2) it is necessary to strengthen courses, both theory and practice, related to Indonesian identity and global culture, hence, every music teacher candidate has the same perception that is accordance with the diversity of Indonesian and world cultures. Therefore, they are rich in experience since there are many material schemes that can be taught. These gaps demand the success of music teacher education institutions in educating and training student music teacher candidates to teach in schools in accordance with the theories they have obtained at the university. The teaching of music must be achieved in conditions of active, creative, fun and democratic learning. This condition can be achieved by instilling intercultural competence, hence in the future they can organize learning that supports diversity of material, culture, student circumstances, methods, teaching materials, textbooks, and teacher competence. Thus, the cultivation of intercultural competences can be an asset for music teachers in delivering teaching materials. With these competencies, it is expected that teachers are no longer confused in delivering curriculum. This research is aimed at discovering suitable formulation of music teacher education and training to equip them with intercultural competence in teacher education institutions in Indonesia.

\section{Literature Review}

\subsection{Intercultural Competence for Music Teacher Education}

The foundation of intercultural competence is based on the nature of teachers who must be able to face and test themselves against diversity, so that they are able to get along in the midst of diverse cultural situations and students (Emmanuel, 2003). Teachers must respond optimally to student's diversity in order to comprehend the strengths and weaknesses of themselves and their students. This understanding can be reflected in the socio-cultural context of students and teachers (Craig et al., 2000; Emmanuel, 2003). Cultivating intercultural competence for prospective teachers aims at providing opportunities for reflection on how to educate students in diverse cultural situations and what material should students learn make them culturally responsible in society. In addition, the teaching process in the classroom should help students develop in an egalitarian and equal manner (Villodre, 2014). According to Villodre (2014), intercultural education is directed at preventing racial and cultural conflicts. Intercultural education does not only instill social harmony, but more than that, to ensure peaceful coexistence of all cultural backgrounds. It does not mean considering cultural exchanges, which still have an impact on racial segregation and rejection of social harmony. Rather, it is to increase maturity in respect for intercultural behavior between the majority and minority cultures.

Barnatt, D’Souza, Gleeson, Viesca, and Wery (2019) asserted that it is fundamental for teacher preparation programs to provide opportunities for prospective teachers to explore diverse cultures. Prospective teachers should leave their comfort zone, step outside their own cultural space, and navigate difficult and confusing situations(Goh, 2012). Specifically, Ehrlich, and Badarne (2020) believed that music teacher educators act for change by negotiating possibilities within classrooms and lecture halls, and even policy reformation. In doing so, a space between policy and institutional dictates and between dictates and practice are opened. Such action begins with belief that "the lives of all students are already filled with meaningful musical practices". By encouraging students to bring such music to class (via recording and/or live performance) Ehrlich and Badarne acted to affirm the conceptualization of all music as legitimate academic knowledge opportunities. They then acted to promote the musical agency of student-teachers, and invited them to be creative about repertoires and pedagogies that they are designing for future classrooms.

Next, Schwarzentha, Schachner, Juang, and van de Vijver (2019), showed that contact and cooperation, color evasion, and multiculturalism in the classroom are uniquely linked to students' intercultural competence. An approach of contact and cooperation may foster the personal and prolonged intercultural experiences that are major for intercultural competence. Color evasion, as in emphasizing a common humanity, may encourage students to look beyond group categories and recognize that humans are still individuals, and may act out of a variety of motives, be they cultural, individual, or interpersonal. A multicultural approach may encourage active reflections on diversity that are important to build intercultural knowledge and awareness. Together, the three approaches may contribute to obtain the benefits of cultural diversity at schools.

For teacher education institution, Barnatt et al. (2019) suggested that teacher preparation faculty should meet teacher candidates as they enter the program. The faculty should offer a range of supported experiences throughout the program sequence for candidate growth in intercultural competence. They found that, for example, the candidates highlighted how courses focused explicitly on diversity and diverse learners were significant in their learning experience. These courses often included practicum and field-based experiences to bridge theory and practice when working with diverse learners. Beyond coursework, candidates valued opportunities in tutoring programs, 
community-based after school programs, domestic service learning experiences, and travelling abroad. Interestingly, the candidates found domestic and international experience equally valuable in their development of intercultural competence. Both types of experiences pushed the candidates to experience cultural dissonance, language challenges, and a need to develop trusting relationships. Ultimately, the quantitative and qualitative data underscored the importance of a range of opportunities to develop intercultural competence while making connections to teaching and learning explicit.

Finally, intercultural education is not to bring communication or intercultural encounters, but rather to fuse between cultures. Intercultural education strongly supports diversity, a sense of respect, intercultural dialogue living in one country and an understanding of another country to ensure dialogue as a basic tool in social harmony. From this perspective, this research leads to the belief that cultural identity must be developed from an intercultural concept, which aims at building a new identity divided into various races, ethnicities, religions, and arts. It all starts with the education and training of prospective teachers who will become intercultural agents when they teach in class.

\section{Method}

\subsection{Research Design and Data Collection}

This research employs case study design as it focuses on a naturally occurring phenomenon in a complex situation (Alwasilah, 2015). The data were obtained from the reflections results of 20 music teacher candidates enrolling at the Department of Music Education, Faculty of Arts and Design Education, Universitas Pendidikan Indonesia, in Bandung, Indonesia, who had carried out teaching internships at schools in the Program Pengalaman Lapangan (PPL - Field Experience Program). They participated in a needs analysis research to develop a music teacher education model that has intercultural competence. 20 semi-structured and recorded interviews with individuals (virtually via email and the WhatsApp) were conducted in July and August 2020. The first interviews were conducted with 5 students on 8 July 2020 (the beginning of project). Then a second interview was conducted with 9 students on 14-21 July 2020 (in the middle of project). Lastly, the third interview was conducted with 6 students on 17 August 2020 (at the end of project). All participants were $7^{\text {th }}$ semester music students/music teacher candidates of class 2016.

The combination of individuals, such as gender, high school education background, experience in apprenticeship places, and specialization of musical instrument expertise were determined to seek a variety of meanings about the intercultural competence they understand. Next, transcriptions were coded. On August 21, 2020, all participants were asked to record their self-reflections about their experiences while doing the teaching internship at the school designated by the campus. However, only six participants shared their reflection. In addition to interviews and reflective notes, observational data were also collected in an unsystematic way, with the aim of giving freedom to the music teacher candidates. The presence of researchers in the field with the candidates, joint discussions, and listening to their complaints, were carried out effectively, efficiently and flexibly. The observation results were important background for understanding the context in which they were working and studying, to minimize bias in the data obtained from the interview activities.

\subsection{Data Analysis}

Most of the interviews were conducted in Indonesian language. Some notes and transcriptions of interviews that were in local language were translated into Indonesian. Then the data were transcribed and analyzed to find recurring codes that emerging from the text. Interviews, diaries and final evaluations are understood as notes (Alwasilah, 2015; Atkinson \& Coffey, 2002; H. Westerlund et al., 2015). To develop the codes, some separated code can be made to indicate the keywords (Alwasilah, 2015). These keywords were developed based on the needs of developing intercultural competences.

\section{Findings and Discussion}

\subsection{Findings}

\subsubsection{Experiencing Listening to Music: Pop Music is More Enjoyable}

The interview showed that most participants listening various styles of music and they tended to prefer Indonesian pop music. It has been confirmed that pop music is more in line with the feelings of every listener. The participants were learning traditional music, even medieval music, Baroque, Classical, Romantic, to contemporary music, which were not included in the school curriculum. However, the experience of attending the lecture provided intercultural understanding of Western culture music. It turned out that most participants preferred and were happy with pop music. It can be inferred that this should be facilitated in the learning process in campus as an addition to other 
intercultural experiences.

\subsubsection{Emerging Attitude during Teaching Internship: Culture Shock}

The candidates started their internship enthusiastically since it was certainly a new experience, where intercultural experiences will inevitably occur. Moreover, they were placed in complex and diverse urban schools, in which lack of learning facilities occurred as well. This became a challenge for the music teacher candidates to observe the reality from new perspectives. Therefore, the candidates should possess adaptive skill to conduct this internship program at school.

Following are the excerpts of interview (translated into English) with several students in the beginning of the internship program:

"I am sure that what I teach students is very useful to encourage them to learn music, both in theory and practice." (FP, interview, 14 July 2020).

"I am sure that I came to school to put the knowledge I had acquired while studying at the Department of Music Education." (DK, interview, 23 September 2020).

On the other hand, although the participants were enthusiastic, some were still cautious when entering a new cultural context.

"In new environment, I am careful in speaking." (SR, interview, 9 July 2020).

"I am confident but still careful in conveying something." (SG, interview 11 July 2020).

I am still careful because I have to understand the characteristics of each student (GJ, interview, 23 September 2020).

In the culture shock stage, 20 participants started to feel uncomfortable with the situation. What they had imagined before was not as easy as expected. Some of them seemed to be pondering what was going to happen. They became more stressed in delivering teaching material to students.

"What I see is that the current generation is very different from mine. So as a teacher, the attitude I take is to be patient and adapt to the circumstances and needs of the students." (MA, interview, 14 July 2020).

At first, I was optimistic about teaching students with different backgrounds. However, in the process, it turned out that it was difficult to convey the messages in the material (TV, interview, 23 September 2020).

However, after two months of their internship, the adjustment stage was over. At this adaptive stage, the candidates were more comfortable with the situation and accepted the reality. Some of them seemed to enjoy the situation and appeared to be more communicative in delivering teaching materials to their students.

"The lesson learned or the lesson that I felt was the improvement of communication and social skills." (SG, interview, 11 July 2020).

"I experienced lessons on how to cultivate appreciation and good communication between cultures." (GS, interview 10 July 2020).

It can be inferred that culture shock had a learning effect on the music teacher candidates. Therefore, they believed that collaborative learning in intercultural situations was indispensable, in which they needed to go outside their comfort zone. In culture shock situations, it was observed that the students were aware of the challenge. They had to have planning, responsibility, and accuracy in making decisions. Culture shock made them see reality not only from their point of view, but also from others. This became a focus on the students' needs, rather than the need for self-satisfaction in teaching situations. This contributed to an awareness of how to view, choose, and act.

\subsection{Discussion}

\subsubsection{Listening Experience: Pop Music}

The importance of cultural diversity has increased the discussion of the diversity of musical genres in the school curriculum (Campbell, 2002), including aspects of pop music. In a global context, it seems that many educational institutions have developed diverse attitudes and views towards variations in music, including popular music (Kim \& Song, 2020). However, some have disputed that there is still a lack of a teaching model for popular music (Dunbar-Hall, 1993) and inadequate resources of inadequate for teaching popular music (Davis \& Blair, 2011). On the other hand, in the interview, the participants illustrated that pop music had a positive impact on their creativity, which were useful to be sources of arrangement and creation. Studies by Kim and Song (2020) and Green (2002, 2006) are in line with that findings, in which they discovered that learning popular music is relevant to culture as a 
benefit of teaching popular music, creating a more positive attitude to be included in the curriculum.

Lebler's (2008) experience in the practice of popular music pedagogy revealed that the inclusion of popular music as a content area in music education is common. In international scope, the musicological study of popular music is well established in higher education, and the practices of popular music are becoming more prevalent in secondary education. However, the interviews showed that pop music was usually studied in student communities as an extracurricular kind of activity, as a self-directed activity in campus. This fact is also emphasized by Lebler (2008) stating that when playing pop music activities, there will be interactions occurring with peers and group activities, which rarely happens under the direction of mentors or expert teachers. In addition, as a means of intercultural education, pop music material can be also used as teaching materials.

\subsubsection{Culture Shock}

Wisterlund, Partti, \& Karlsen (2015) and Tange (2010) emphasized three progressive stages characterizing learning in adapting to new contexts, namely: arrival, culture shock, and adjustment. The arrival stage can be referred to as a honeymoon phase and is generally characterized by "a high degree of enthusiasm and excitement about cultural differences". The culture shock stage may not be quite as pleasant. During this second stage, negative reactions to intercultural relationships results in increasing levels of uncertainty and anxiety. In other words, the participants experienced an increased sense of frustration and anger regarding their exposure to unfamiliar contexts and ways of doing and being. Lastly, in the adjustment stage, the participants completed their "intercultural learning process" and are often able to view their own behavior and reactions more objectively, even with a dose of humor towards themselves.

\subsubsection{The Concept of Intercultural Competence in the Indonesian Context}

Diversity is not merely about race, ethnicity and language; it is also about pedagogy, developing teaching materials, and using existing facilities. The new view of teaching also shifts, from transferring knowledge into the awareness that teachers are not just teaching, but also educating. These new perspectives were revealed from the participants' reflection notes. Those studying in a university may be skilled and trained in musical skills; however, in the internship program, these skills could be meaningless if intercultural competence in teaching is neglected. It is in accordance with Emmanuel (2003), Villodre (2014) and Hernández-Bravo, Cardona-Moltó, \& Hernández-Bravo (2017) stating that prospective music teachers in the Music Education Department who are participating in teaching internships do not only need music skills, but also communication and socializing skills.

Most students were found enjoying pop music. Hence, this must be facilitated in the learning process, as an addition to teaching material in the intercultural music learning experience. Kim and Song (2020) stated that the characteristics of pop music are comprehended from the aspect of its use. The interviews revealed that the easy listening nature of pop music had attracted the participants in musical activities, which triggers their interest in classroom learning.

It can be inferred that pop music provided a meaningful experience, at least in the case of the current research. This is in line with May et al. (2020) stating that finding popular music resources is easy since they are widespread in many activities of daily life. Consequently, there are many opportunities for learners to engage in meaningful musical interactions involving performance, creation, response, and thinking about popular music texts (sources) leading to the development of musical literacy. The access to popular music has also become practically automatic on modern electronic devices. It permeates TV shows, commercials, movies, sporting events, social functions, and even dining and shopping. Popular music instruments are often portable, accessible, and relatively affordable. Online resources also provide accessible instruction on how to play an instrument. Music educators can easily facilitate students to engage meaningfully with these resources as texts to develop music literacy (May et al., 2020).

Based on these findings, pop music should be utilized as teaching material in the process of education and training for music teachers. Choosing materials, teaching method and process, and evaluation techniques must be considered by music teacher education institutions. This is fundamental considering the access of students in finding popular music is effortless. Without leaving the established traditional music teaching materials, music teacher candidates should also be equipped with popular music pedagogy to anticipate many teaching situations.

\subsubsection{Development of Intercultural Music Teacher Education Design}

Drawing on the range of research that has been conducted and the numerous conceptual models that have been proposed, Barrett (2012) asserted that all of the following components form the core of intercultural competence:

- Attitudes: respect for other cultures; curiosity about other cultures; willingness to learn about other cultures; 
openness to people from other cultures; willingness to suspend judgement; willingness to tolerate ambiguity; and valuing cultural diversity.

- Skills: skills of listening to people from other cultures; skills of interacting with people from other cultures; skills of adapting to other cultural environments; linguistic, sociolinguistic and discourse skills, including skills in managing breakdowns in communication; skills in mediating intercultural exchanges; skills in discovering information about other cultures; skills of interpreting cultures and relating cultures to one another; empathy; multiperspectivity; cognitive flexibility; and skills in critically evaluating cultural perspectives, practices and products, including those of one's own culture.

- Knowledge: cultural self-awareness; communicative awareness, especially of the different linguistic and communicative conventions within different cultures; culture specific knowledge, especially knowledge of the perspectives, practices and products of particular cultural groups; and general cultural knowledge, especially knowledge of processes of cultural, societal and individual interaction.

- Behaviors: behaving and communicating effectively and appropriately during intercultural encounters; flexibility in cultural behavior; flexibility in communicative behavior; and having an action orientation, that is, a disposition for action in society in order to enhance the common good, especially through the reduction of prejudice, discrimination and conflict.

Based on Barrett (2012), the aforementioned components have not been well established. This has become an empirical investigation rather than a priori theorizing, which results in agendas to be addressed. However, this research on intercultural competence is in line with what the current Indonesian Minister of Education and Culture, Nadiem Makarim, calls Merdeka Belajar-Kampus Merdeka (Learning Freedom-Campus Freedom). Music teacher candidates are given the opportunity to take three semesters longer to study outside the study program. During those three semesters, students can study in a similar study program at partner universities, internships at schools, industry, or arts institutions, and internationalization through student exchanges. What is expected in the intercultural competency component (Barrett, 2012) from the music teacher candidates is in line with ministry policies. Thus, the case analyzed strengthens Lasauskiene's (2018) research that the development of various intercultural competencies (Barrett, 2012) for student music teacher candidates is significant to envisage broader perspectives for personality education, development of personal and professional values and attitudes

\section{Conclusions}

Education and training of music teacher candidates with an intercultural competency scheme needs to be implemented in universities considering that music teacher candidates must possess sensitivity to cultural diversity. This is necessary to develop beliefs that schools, students, curricula, teaching systems, etc. are not only seen from the point of view of own culture. Hence, it is expected that there will be a growing awareness of the existence of many other points of view by strengthening both theoretical and practical subjects related to Indonesian identity and global culture. This is necessary to make every music teacher candidate having the same perception, which is in accordance with the cultural diversity in Indonesia and the world to help students develop diverse understanding of music. This research needs to be further developed by examining the relationship between the various attitudes, skills, knowledge, and behaviors related to intercultural competence. In addition, the development of each intercultural component in student music teacher candidates includes social, cognitive, and motivational factors that affect the acquisition of each component and its intercultural competence.

\section{Acknowledgement}

We would like to thank the Directorate General of Higher Education of the Ministry of Education and Culture (DIKTI, Direktorat Jenderal Pendidikan Tinggi, Kementerian Pendidikan dan Kebudayaan) for awarding us with the grant number 540/UN40.A8/PP/2020 and The Institute of Research and Community Service (LPPM, Lembaga Penelitian dan Pengabdian Masyarakat) of Universitas Pendidikan Indonesia.

\section{References}

Alwasilah, A. C. (2015). Pokoknya Studi Kasus: Pendekatan Kualitatif. Kiblat Buku Utama.

Atkinson, P. A., \& Coffey, A. (2002). Revisiting the relationship between participant observation and interviewing. In J. F. Gubrium \& J. A. Holstein (Eds.), Handbook of interview research (pp. 801-814). Sage. https://doi.org/10.4135/9781412973588.n46

Banks, J. A., \& McGee Banks, C. A. (2019). Preface. In J. A. Banks \& C. A. McGee Banks (Eds.), Multicultural education: Issues and perspectives (9th ed., pp. v-viii). Wiley. 
Barnatt, J., D'Souza, L. A., Gleeson, A. M., Viesca, K. M., \& Wery, J. (2019). Intercultural competence in pre-service teacher candidates. International Journal of Educational Reform, 29(3), 211-235. https://doi.org/10.1177/1056787919896866

Barrett, M. (2012). Intercultural competence. EWC Statement Series, 2nd Issue. European Wergeland Centre.

Campbell, P. S. (2002). Music education in a time of cultural transformation. Music Educators Journal, 89(1), 27-32. https://doi.org/10.2307/3399881

Craig, S., Hull, K., Haggart, A. G., \& Perez-Selles, M. (2000). Promoting cultural competence through teacher assistance teams. Teaching Exceptional Children, 32(3), 6-12. https://doi.org/10.1177/004005990003200302

Davis, S. G., \& Blair, D. V. (2011). Popular music in American teacher education: A glimpse into a secondary methods course. International Journal of Music Education, 29, 124-140. https://doi.org/10.1177/0255761410396962

Dunbar-Hall, P. (1993). Designing a teaching model for popular music. International Journal of Music Education, 21, 16-24. https://doi.org/10.1177/025576149302100102

Ehrlich, A., \& Badarne, B. (2020). Intercultural music teacher education in Israel: Reimagining religious segregation through culturally responsive reaching. In Heidi Westerlund, S. Karlsen, \& H. Partti (Eds.), Visions for Intercultural Music Teacher Education (pp. 31-46). Springer Open. https://doi.org/10.1007/978-3-030-21029-8_3

Emmanuel, T. (2003). An immersion field experience: An undergraduate music education course in intercultural competence. Journal of Teacher Music Education, 13(1), 33-41. https://doi.org/10.1177/10570837030130010105

Goh, M. (2012). Teaching with cultural intelligence: Developing multiculturally educated and globally engaged citizens. Asia Pacific Journal of Education, 32(4), 395-415. https://doi.org/10.1080/02188791.2012.738679

Green, L. (2002). From the Western classics to the world: Secondary music teachers' changing attitudes in England, 1982 and 1998. British Journal of Music Education, 19, 5-30. https://doi.org/10.1177/S0265051702000116

Green, L. (2006). Popular music education in and for itself, and for "other" music: Current research in the classroom. International Journal of Music Education, 24, 101-118. https://doi.org/10.1177/ 0255761406065471

Hernández-Bravo, J. A., Cardona-Moltó, M. C., \& Hernández-Bravo, J. R. (2017). Developing elementary school students' intercultural competence through teacherled tutoring action plans on intercultural education. Intercultural Education, 28(1), 20-38. https://doi.org/10.1080/14675986.2017.1288985

Kim, Y. J., \& Song, M. K. (2020). Exploring teachers' approaches to popular music: Attitudes, learning practice, and issues in South Korea. International Journal of Music Education, 38(3), 456-469. https://doi.org/10.1177/0255761420919570

Lasauskiene, J. (2018). An Innovative Pedagogical Design of Intercultural Competence Development in Music Teacher Education. Rural Environment. Education. Personality, 11, 208-214. https://doi.org/10.22616/REEP.2018.025

Lebler, D. (2008). Popular music pedagogy: Peer learning in practice. Music Education Research, 10(2), 193-213. https://doi.org/10.1080/14613800802079056

May, B., Nixon, P. B., \& Tsugawa, S. (2020). A music literacy-based rationale for popular music ensambles and experiences in music education. International Journal of Music Education, 38(3), 470-491. https://doi.org/10.1177/0255761420923186

Schwarzenthal, M., Schachner, M. K., Juang, L. P., \& van de Vijver, F. J. R. (2019). Reaping the benefits of cultural diversity: Classroom cultural diversity climate and students' intercultural competence. European Journal of Social Psychology, 50(2), 323-346. https://doi.org/10.1002/ejsp.2617

Sukmayadi, Y., \& Gunara, S. (2018). Intercultural competencies for education and training the prospective music teachers. Proceedings of International Conference on Arts and Design Education, 267-269. https://doi.org/10.2991/icade-18.2019.61

Tange, H. (2010). International education as intercultural learning: An employee perspective. In M. Hellstén \& A. Reid (Eds.), Researching international pedagogies: Sustainable practice for teaching and learning in higher education, (pp. 99-114). Springer. https://doi.org/10.1007/978-1-4020-8858-2_7 
Villodre, M. D. M. (2014). Cultural identity and using music in the intercultural educational process. Social and Behavioral Sciences, 132, 235-240. https://doi.org/10.1016/j.sbspro.2014.04.304

Westerlund, H., Partti, H., \& Karlsen, S. (2015). Teaching as improvisational experience: Student music teachers' reflections on learning during an intercultural project. Research Studies in Music Education, 37(1), 55-75. https://doi.org/10.1177/1321103X15590698

\section{Copyrights}

Copyright for this article is retained by the author(s), with first publication rights granted to the journal.

This is an open-access article distributed under the terms and conditions of the Creative Commons Attribution license (http://creativecommons.org/licenses/by/4.0/). 